\title{
Is there an Advantage of Subchondral Drilling and Bone Marrow to Hyaluronic Acid Injection at Rabbit's Knee Osteoarthritis? An Experimental Study
}

\section{Tavșan Diz Osteoartritinde Hyalüronik Asit Enjeksiyonuna Göre Subkondral Delme ve Kemik iliğinin Avantajı Var mı? Deneysel Bir Çalıșma}

\author{
(D) Bülent Kılıç11, (D) Yalçın Turhan2, (1) Mehmet Arıcan2, (D) Zekeriya Okan Karaduman2, (D) Mehmet Gamsızkan33, \\ (D) Ozan Turhal4, (1) Yusuf İyetin5, (1) Anıl Agar1 \\ IUniversity of Health Sciences Turkey, İstanbul Kanuni Sultan Süleyman Training and Research Hospital, Clinic of Orthopaedics and Traumatology, \\ İstanbul, Turkey \\ 2Düzce University Faculty of Medicine, Department of Orthopedics and Traumatology, Düzce, Turkey \\ ${ }^{3}$ Düzce University Faculty of Medicine, Department of Pathology, Düzce, Turkey \\ 4Düzce Atatürk State Hospital, Clinic of Orthopedics and Traumatology, Düzce, Turkey \\ ${ }^{5}$ Private Pendik Bolge Hospital, Clinic of Orthopedics and Traumatology, İstanbul, Turkey
}

\begin{abstract}
Objective: The objective of this study is to compare the individual histopathological changes caused by subchondral drilling (SCD) and bone marrow injection accompanied by hyaluronic acid (HA) in rabbits with knee osteoarthritis (OA) that is stimulated by the anterior cruciate ligament transection.

Method: An OA design was created in 20 New Zealand rabbits, which were then randomly divided into two groups of ten rabbits each. The first group was named as the SCD group, in which $0.3 \mathrm{~mL}$ bone marrow aspirate was taken from the proximal medial tibial region and injected into the same knee joint; thereafter, retrograde SCD was applied to the proximal tibial region. The second group (HA) received intra-articular injections of $0.3 \mathrm{~mL} H A$ oil once weekly for three weeks. The knee joints were removed nine weeks post-surgery after the animals were killed. The knee joint articular cartilage areas were examined macroscopically, and the medial femoral condyle sections were examined histopathologically.

Results: Significantly better macroscopic grading results were observed in the SCD group than in the HA group ( $p=0.0001$ ). There was no significant difference in the OA cartilage histopathology $(\mathrm{OACH})$ grade between the groups $(\mathrm{p}=0.752)$, but the SCD group showed a significantly better OACH stage result than the HA group ( $p=0.039)$. The total OACH score inclined to be lower in the SCD group than in the HA group ( $p=0.192)$.

Conclusion: This study demonstrated that SCD with intra-articular bone marrow injection slowed the progression of OA and protected the cartilage surface during the early stages of $\mathrm{OA}$ better than $\mathrm{HA}$.
\end{abstract}

Keywords: Osteoarthritis, bone marrow, rabbit, hyaluronic acid

\section{öz}

Amaç: Bu deneysel çalıșmanın amacı, ön çapraz bağın kesilerek indüklenen diz osteoartritli (OA) tavşanlarda subkondral drilleme (SKD) ve kemik iliği enjeksiyonu ile eklem içi hyalüronik asit (HA) enjeksiyonunun kıkırdaktaki histopatolojik değișikliklerinin karșılaștırmaktır.

Yöntem: Yirmi adet Yeni Zelanda tavșanının ön çapraz bağları kesilerek osteoartrit modeli olușturuldu, tavșanlar her grupta 10 adet olacak șekilde rastgele 2 gruba ayrıldı. Illk grup bu tavşanların medial tibial bölgelerine retrograd subkondral drilleme uygulandıktan sonra proksimal medial tibial bölgeden 0,3 mL

Cite as: Kılıc B, Turhan Y, Arıcan M, Karaduman ZO, Gamsızkan M, Turhal O, İyetin Y, Agar A. Is there an Advantage of Subchondral Drilling and Bone Marrow to Hyaluronic Acid Injection at Rabbit's Knee Osteoarthritis: An Experimental Study. IKSSTD 2021;13(2):85-91 
kemik iliği aspiratının alınarak aynı diz eklemine enjekte edildiği SKD grubuydu. İkinci gruba (HA), 3 hafta süreyle haftada bir kez 0,3 mL HA intraartiküler enjeksiyonu uygulandı. İșlemden 9 hafta sonra diz eklemleri cerrahi olarak çıkarıldı. Diz eklemi yüzeyleri makroskopik, medial femoral kondil kesitleri ise mikroskopik olarak incelendi.

Bulgular: SKD grubunda HA grubuna göre anlamlı derecede daha iyi makroskopik derecelendirme sonuçları gözlendi ( $p=0,0001)$. 0A kıkırdak histopatolojisi (OACH) evrelerinin gruplar arasında farkı anlamlı değildi ( $p=0,752)$, ancak SKD grubu HA grubundan daha iyi bir OACH evresine sahipti ( $p=0,039)$. Toplam OACH skoru SKD grubunda HA grubundan daha düşük bulundu ( $p=0,192)$.

Sonuç: Medial tibia metafiz kemiğin subkondral drillemesi ile birlikte eklem içi kemik iliği enjeksiyonu osteoartritin erken evrelerinde eklem kıkırdağını koruyucu etkisi vardır.

Anahtar kelimeler: Osteoartrit, kemik iliği, tavșan, hyalüronik asit

\section{INTRODUCTION}

Knee osteoarthritis (OA) is a common joint problem that involves the degeneration of cartilage and poses a significant burden to the society ${ }^{(1)}$. It includes the inflammation and degradation of the synovial tissue and articular cartilage, respectively. The progression of this disease is accompanied by osteophyte formation at the joint margins and the remodeling of the subchondral bone ${ }^{(2)}$. Different treatment methods for knee OA are available. With the increasing incidence of $\mathrm{OA}$, the demand for joint replacement surgery is predicted to grow rapidly ${ }^{(3-5)}$. The combined treatment such as periarticular lidocaine-corticosteroid injection with intraarticular hyaluronic acid (HA) may provide more effective pain control as compared with the intra-articular injection of HA alone in patients with knee OA and can be used as a successful adjunctive treatment modality. This combined injection may improve daily activities of a patient ${ }^{(6)}$. The objective of this study is to compare a combined treatment of subchondral drilling (SCD) with bone marrow injection and $\mathrm{HA}$, and show a possible effectiveness of the combined treatment.

Many patients with early knee $\mathrm{OA}$ are being treated with a variety of nonsurgical modalities, such as physical therapy, bracing, non-steroidal anti-inflammatory drugs, intraarticular HA or corticosteroid injections ${ }^{(7)}$. These treatment modalities aim to decrease morbidity associated with pain and provide a better range of motion and function. Intraarticular HA injection is a commonly used nonsurgical approach for treating knee OA. The HA injection into the knee joint offer many benefits with the combination of its viscoelastic properties with anti-inflammatory, anabolic, analgesic, and chondroprotective properties ${ }^{(8)}$.

Although the subchondral bone is increasingly blamed to play a major role in the disease process, there is an ongoing debate about its role in the pathogenesis of OA. The area underlying the calcified cartilage, which comprises the subchondral bone plate and subchondral trabecular bone, is involved in the pathogenesis of OA. Kilic et al. ${ }^{(9)}$ presented a new treatment approach for patients with moderate to advanced gonarthrosis. In their study, patients underwent a minimally invasive treatment protocol comprising retrograde SCD of the proximal tibia, release of the percutaneous medial collateral ligament, and the injection of whole bone marrow containing mesenchymal stem cells and supportive chondrogenic components into the knee, all under local anesthesia. Pan et al. ${ }^{(10)}$ reported on the penetration of small molecules into the calcified cartilage from the subchondral bone, where the subchondral bone plate provides a direct link between this bone and the articular cartilage. Chondrogenic bone marrow-derived mesenchymal stem cells are usually prepared as a buffy coat fraction of the bone marrow. However, whole bone marrow retains the supportive chondrogenic components in the marrow plasma, including marrow adipocytes, which have important functions during chondrogenesis ${ }^{(11)}$.

In this experimental study, we compared the histopathological changes caused by intra-articularly administered hyaluronate and SCD with bone marrow injection in rabbits with knee $\mathrm{OA}$.

\section{METHODS}

\section{Animals}

The Laboratory Animal Ethics Committee of Abant Izzet Baysal University, Bolu/Turkey (decision no: 2017/20) approved this study. In total, 20 mature New Zealand white rabbits (males, 5-7 months old, 2.5-3.0 kg) were provided by the Laboratory Animal Center of Abant Izzet Baysal University (Bolu, Turkey). The animals were placed in separate metal cages and allowed free mobility to a solid diet and distilled water under a natural light-dark cycle. 


\section{Surgery}

In total, $20 \mathrm{mg} / \mathrm{kg}$ of cefazolin sodium was administered intramuscularly as antibiotic prophylaxis $30 \mathrm{~min}$ preoperatively, and an additional dose was given $8 \mathrm{~h}$ postoperatively to terminate the antibiotic prophylaxis procedure. All animals were anesthetized with $50 \mathrm{mg} / \mathrm{kg}$ of ketamine hydrochloride (Ketalar; Pfizer Warner Lambert, Waltham, MA, USA) and an intramuscular injection of 10 $\mathrm{mg} / \mathrm{kg}$ of xylazine (Rompun; Bayer, Istanbul, Turkey). The right knee joint skin surface of each rabbit was shaved and then disinfected with polyvinyl iodine (Betadine; Eczacıbașı, Istanbul, Turkey), followed by skin incision starting from the superior pole of the patella extending to the tibial tuberosity. After entering the joint with medial parapatellar arthrotomy, the anterior cruciate ligament was seen and cut with a surgical blade (Figure 1). A positive anterior drawer test was conducted to verify the complete resection of the ligament ${ }^{122)}$. Then, the joint space was washed with physiological saline solution followed by the suturing of the medial retinacular

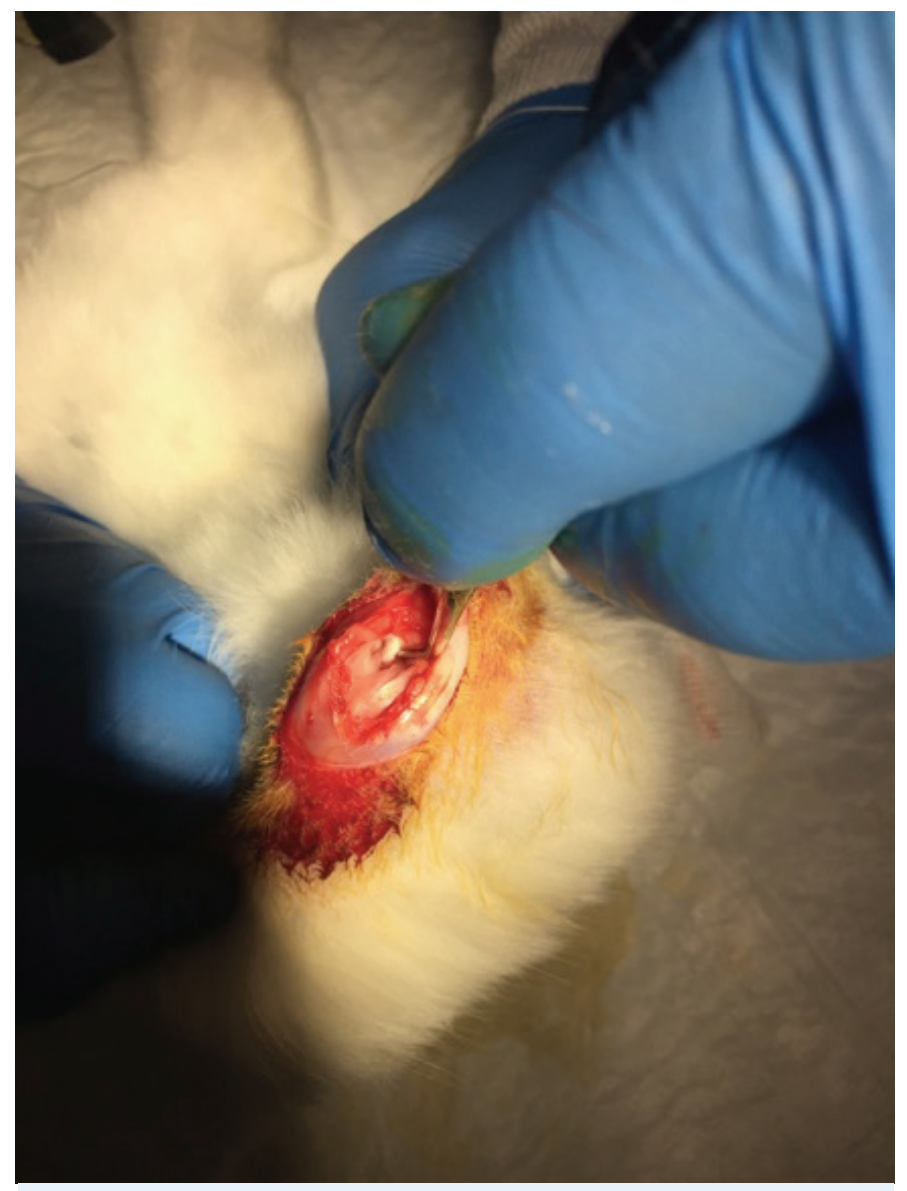

Figure 1. The anterior cruciate ligament was visualized and transected tissues and the closure of subcutaneous tissues with $4 / 0$ Vicryl sutures and the skin with 4/0 Prolene, respectively. Finally, a wound dressing with sterile gauze was applied to the wounds, and the animals were left to recover. The animals were allowed free mobility postoperatively. An OA design was created in 20 New Zealand rabbits by cutting the anterior cruciate ligament ${ }^{(13)}$. The principles of laboratory animal care were followed strictly during the study, and all operative procedures were conducted in accordance with the National Institutes of Health Guide for the Care and Use of Laboratory Animals with the approval from the local animal care committee.

\section{Intra-articular Injections}

After the anterior cruciate ligament resection, the rabbits were randomly allocated to two groups comprising ten rabbits each: the SCD and HA groups. Six weeks after the first operation, rabbits in the SCD group were anesthetized with an intramuscular injection of $10 \mathrm{mg} / \mathrm{kg}$ of xylazine and $50 \mathrm{mg} / \mathrm{kg}$ of ketamine hydrochloride. The right knee joint skin surface of each rabbit was shaved and disinfected with polyvinyl iodine. Approximately $1 \mathrm{~cm}$ long cutaneous and subcutaneous incision was made with a surgical blade on the medial side of tibial tuberosity. Then, $0.3 \mathrm{~mL}$ of bone marrow aspirate was taken from the proximal medial tibial region with a syringe, and the aspirate was injected into the same knee joint. Thereafter, the retrograde SCD of the proximal tibial region was applied through this entry point with a Kirchner wire (to increase blood supply to the sclerosing subchondral bone). Subcutaneous tissues were then closed with 4/0 Vicryl sutures and the skin with 4/0 Prolene. Sterile gauze was applied to the wounds and the animals were left to recover. The same investigator performed all the interventions (Figures 2-4).

Six weeks after the anterior cruciate ligament resection, the HA group received intra-articular injections of $0.3 \mathrm{~mL} \mathrm{HA}$ oil (25 mg/2.5 mL, Adant; Meiji Seika Kaisha, Japan) once weekly for three weeks. The same investigator administered all the injections. All rabbits were killed using highdose intravenous thiopentone sodium (Pentothal; Abbott Laboratories, Abbott Park, IL, USA) after the intramuscular administration of anesthesia with xylazine and ketamine nine weeks after the anterior cruciate ligament resection.

\section{Morphological Evaluation}

The distal femurs and proximal tibiae of the rabbits were removed after the animals were killed. Each animal's articular cartilages were stained with India ink. Gross 
morphological assessment (GMA) of the knee joints was performed using the scoring system described in 1972 by Meachim based on the articular cartilage evaluation as: grade 1 , intact surface (joint surface does not retain India ink); grade 2, minimal fibrillation (joint surface retains India ink as light gray patches); grade 3, overt fibrillation (areas of the joint surface are velvety in appearance and retain India ink as intense black patches); and grade 4, erosion (loss of cartilage exposing the underlying bone) ${ }^{(14)}$.

\section{Histopathological Evaluation}

The distal femurs of the knee joints were placed in $10 \%$ buffered formalin solution and then decalcified in a buffered

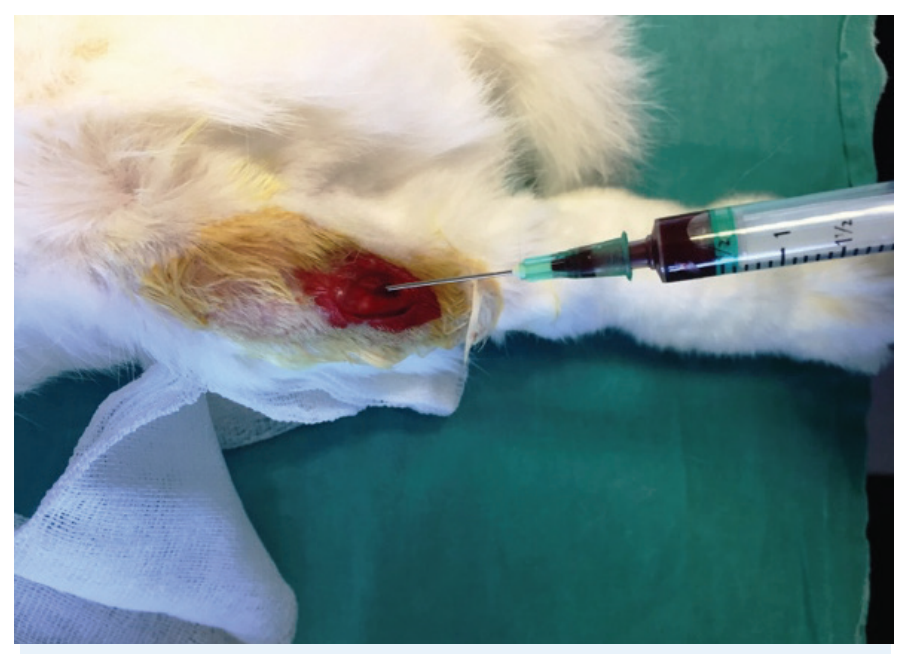

Figure 2. Approximately $0.3 \mathrm{~mL}$ of bone marrow aspirate was taken from the proximal medial tibial region by a syringe

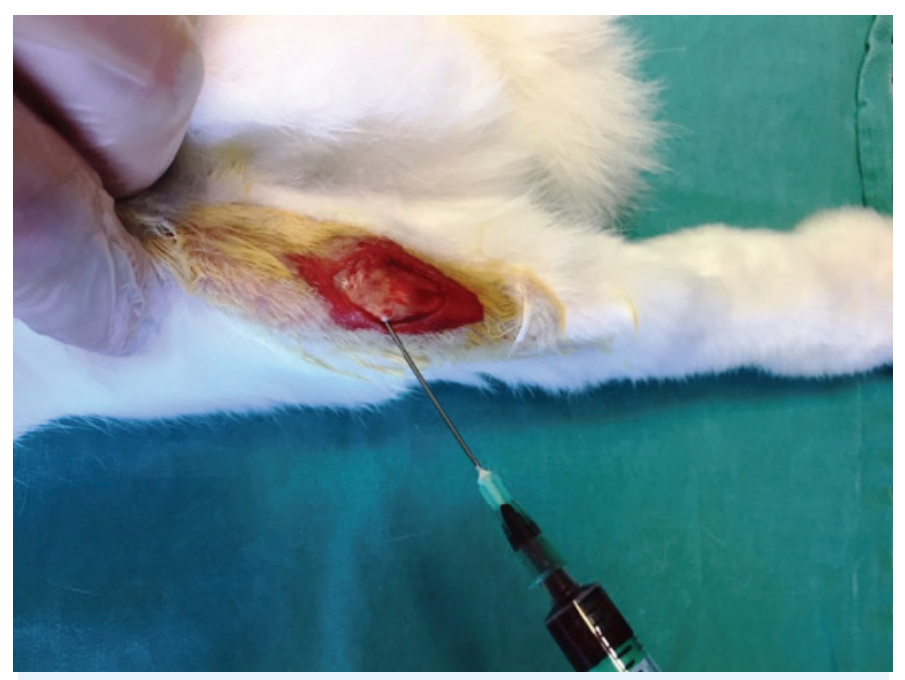

Figure 3. The aspirated bone marrow was injected to the same knee joint formic acid solution. In total, sections measuring $5 \mu \mathrm{m}$ were obtained from the distal femur articular surfaces, which were embedded in paraffin after processing. The histopathological slides were stained with hematoxylin and eosin and safranin 0 ; then, they were examined with a light microscope. To avoid any bias, a single musculoskeletal histopathologist blinded to the study evaluated all variables. Histopathological characteristics were assessed as described by Pritzker et al., and OA Cartilage Histopathology (OACH) grades, stages, and scores were calculated. Briefly, $\mathrm{OACH}$ grades are: 0, normal; 1 , surface intact; 2 , surface discontinuity; 3 , vertical fissures; 4, erosion; 5, denudation; and 6, deformation. The percentage of joint involvement $(\mathrm{OACH}$ stage) was classified using four categories: 0 , no OA activity observed; $1,<10 \% ; 2,10-25 \%$; $3,25-50 \%$; and $4,>50 \%$. A total $\mathrm{OACH}$ score for each case was determined by multiplying the histopathological grade by the percentage of joint involvement ${ }^{(15)}$.

\section{Statistical Analysis}

IBM SPSS Statistics 22.0 program was used for statistical analysis while evaluating this study's findings. The MannWhitney $U$ test was used for comparing the parameters at the level of ranking measurement between the two groups. Significance was evaluated at $p<0.05$ level.

\section{RESULTS}

During the experimental period, no rabbit died, and no superficial or deep infectious condition was detected in any of the knees. The total GMA scores in the SCD group were between 1 and 2 , with a mean of $1.40 \pm 0.52$ and a median

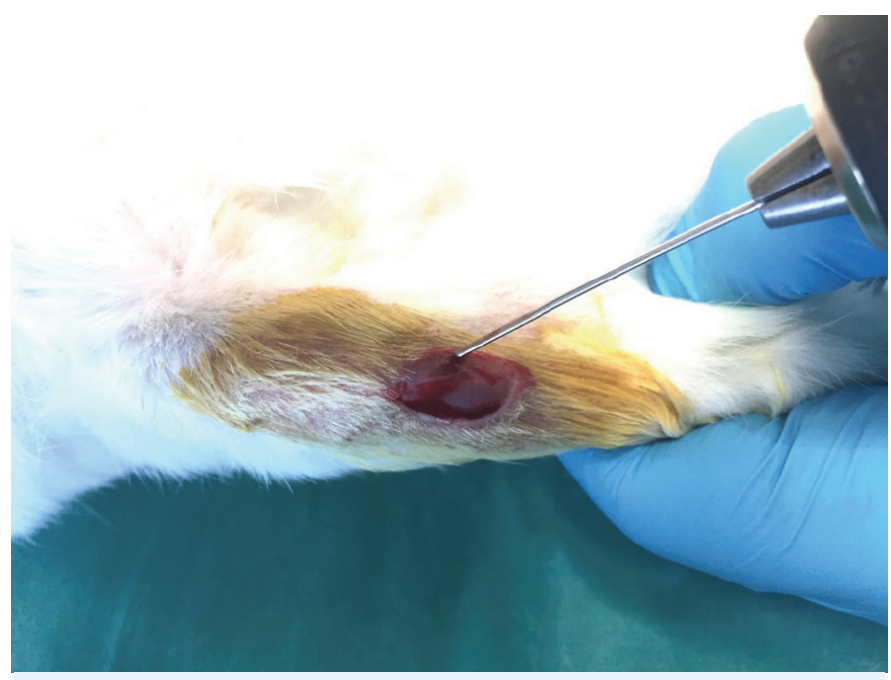

Figure 4. Through this entry point in Figure 2, the retrograde subchondral drilling of the proximal tibial region by a Kirchner wire was applied 
of 1. The total GMA scores in the HA group were between 2 and 4 , with a mean of $2.90 \pm 0.88$ and a median of 2 . The macroscopic grading results differed significantly between the groups ( $p=0.0001$; Table 1 ).

The $\mathrm{OACH}$ grade (median-IR) in the SCD group was between 2.0 and $1.0(p=0.752)$. The $\mathrm{OACH}$ grade (median-IR) in the HA group was between 2.5 and 3.25 ( $p=0.752)$, (Figures 5 and 6). The OACH stage (median-IR) in the SCD group was between 1.0 and $0.25(p=0.039)$. The $\mathrm{OACH}$ stage (medianIR) in the HA group was between 2.0 and $2.25(p=0.039)$. The total OACH score (median-IR) in the SCD group was between 2.0 and 1.75. The total $\mathrm{OACH}$ score (median-IR) in the HA group was between 6.5 and 8.25. The mean $\mathrm{OACH}$ scores were lower in the SCD group as compared with the HA group, but this difference was not significant ( $p=0.192$; Table 1$)$.

There is no statistically significant difference between the $\mathrm{OACH}$ grade measurements according to the groups ( $p>$ 0.05). The $\mathrm{OACH}$ stage measurement of the control group is statistically significantly higher than the SCD group ( $p<$ 0.05). There is no statistically significant difference between the $\mathrm{OACH}$ score measurements according to the groups ( $p$ $>0.05$ ).

\section{DISCUSSION}

The most important result of this study is that SCD with bone marrow injection yielded favorable histopathological outcomes as compared to the HA injection. Rabbits receiving intra-articularly administered bone marrow with SCD presented fewer signs of $O A$ than those receiving intraarticularly administered $\mathrm{HA}$.

The $\mathrm{OACH}$ grade and stages tended to be better in the SCD group than in the HA group. Intra-articular injections of different HAs are used for chondroprotection in the treatment of $\mathrm{OA}{ }^{(16-18)}$. Accordingly, histological profiles of the knee cartilage were better in animals who received SCD with bone marrow injection, with a lower $\mathrm{OACH}$ grade

Table 1. Distribution of the groups according to the gross morphological assessment and osteoarthritis cartilage histopathology scores

\begin{tabular}{|c|c|c|c|}
\hline & $\begin{array}{l}\text { HA group } \\
(n=10)\end{array}$ & $\begin{array}{l}\text { SCD } \\
(n=10)\end{array}$ & bp \\
\hline $\mathrm{OACH}$ grade (median-aIR) & $2.5-3.25$ & $2.0-1.0$ & 0.752 \\
\hline OACH stage (median-IR) & $2.0-2.25$ & $1.0-0.25$ & $0.039 *$ \\
\hline OACH score (median-IR) & $6.5-8.25$ & $2.0-1.75$ & 0.192 \\
\hline \multicolumn{4}{|c|}{$\mathrm{p} p<0.05$, al $\mathrm{R}=$ Interquartile range, ${ }^{\mathrm{b}} \mathrm{Mann}$-Whitney $\mathrm{U}$ test } \\
\hline \multicolumn{4}{|c|}{$\begin{array}{l}\text { HA: Hyaluronic acid, SCD: Subchondral drilling, OACH: Osteoarthritis cartilage } \\
\text { histopathology }\end{array}$} \\
\hline
\end{tabular}

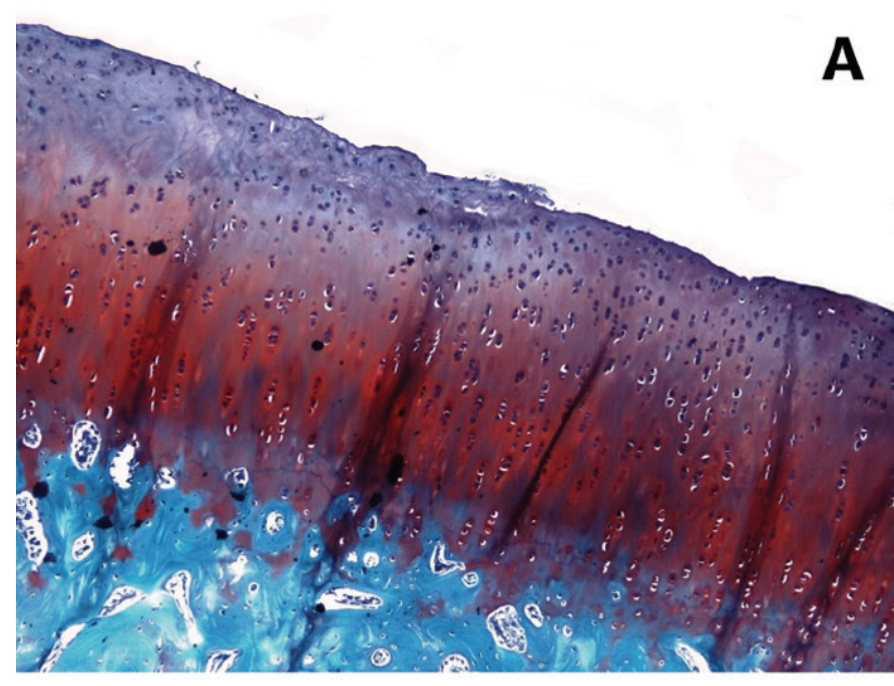

B
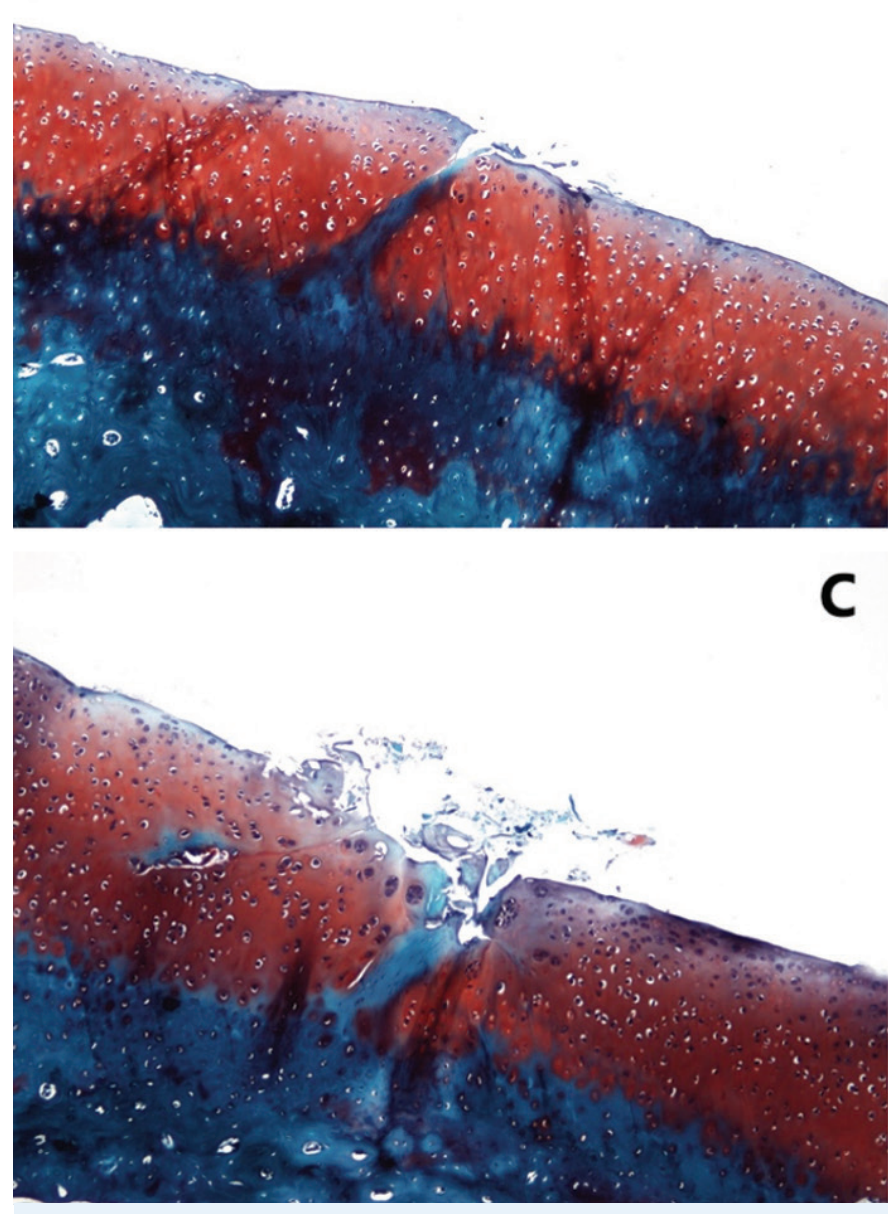

Figure 5. $\mathrm{A}, \mathrm{OACH}$ grade $\mathrm{l}_{\text {; }}$ cartilage surface intact but local superficial fibrillation is present. $\mathrm{B}, \mathrm{OACH}$ grade 2 ; discontinuity of surface. $\mathrm{C}, \mathrm{OACH}$ grade 3 ; vertical fissure formation (safranin 0, 100x) 


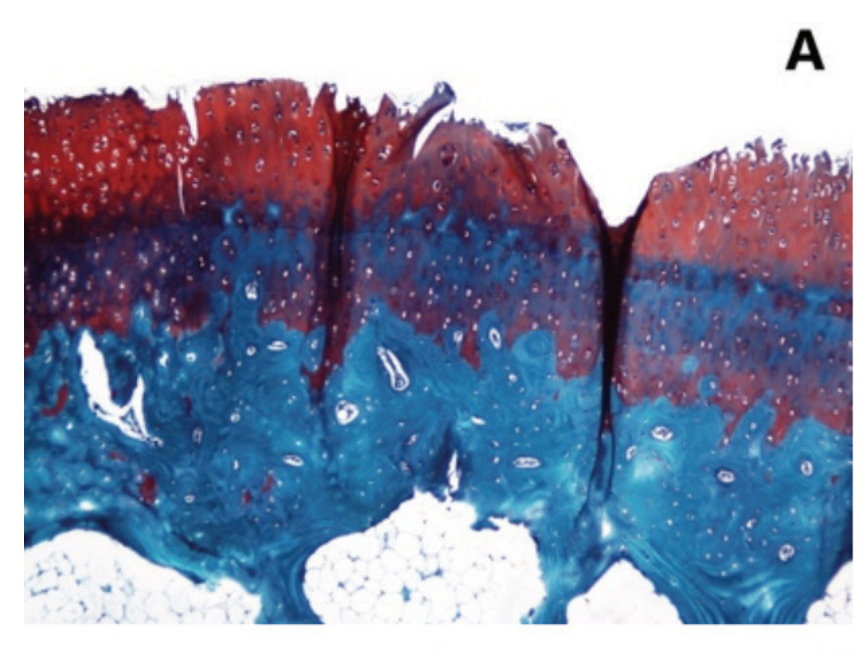

B

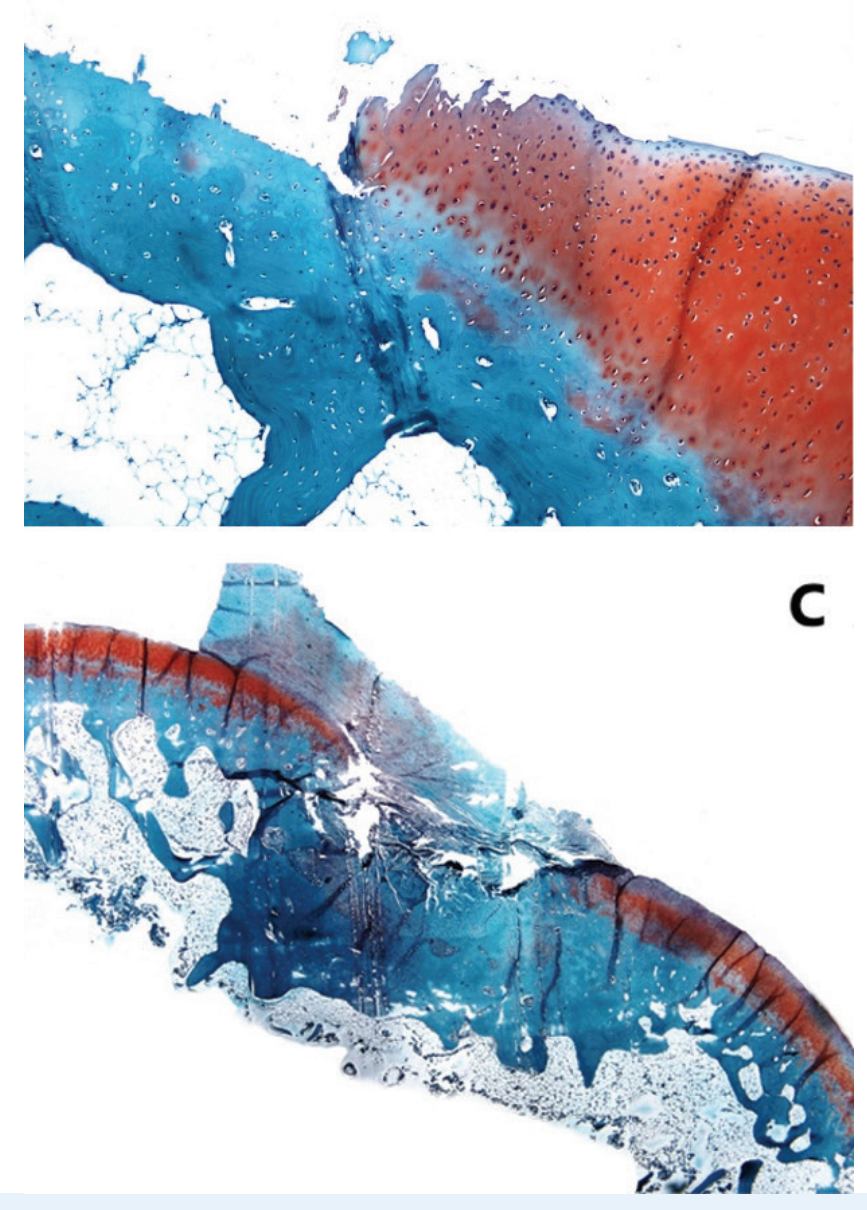

Figure 6. $\mathrm{A}, \mathrm{OACH}$ grade 4; superficial erosion and loss of matrix in fissured domains (Safranin 0, 100x). B, OACH grade 5; denudation and loss of cartilage (Safranin 0 , 100x). C, OACH grade 6; deformation; changing of the contour of the articular surface because of repair and bone remodeling (safranin $0,40 x$ ) and stage as compared with the HA group. The GMA and $\mathrm{OACH}$ scores were significantly better in the SCD group than in the HA group. We suggest that these results are related to vascular changes in the subchondral bone and changes in the cartilaginous matrix through the reduction of intraosseous perfusion and consequent hypoxia, as reported by Aaron et al. ${ }^{(19)}$. Bone marrow can slow down the progression of $\mathrm{OA}$, as demonstrated in early studies ${ }^{(20,21)}$. This effect may be related to the paracrine effects of pluripotent stem cells on illicit regeneration, as mentioned be other researchers ${ }^{(22,23)}$. Furthermore, the cell viability was preserved in those animals, with lower GMA and OACH scores after SCD and HA injection. Although the results were better in the SCD group, the lower histopathological scores reflect beneficial effects of both treatment methods in terms of OA prevention and articular cartilage preservation.

$\mathrm{HA}$ is a type of glycosaminoglycan and one of the major ingredients of synovial fluid. It reduces the secretion of arachidonic acid from synovial fibroblasts and stimulates the tissue inhibitor of metalloproteinase- 1 in articular chondrocytes (24). Takahashi et al. ${ }^{(25)}$ demonstrated that the production of nitric oxide in the meniscal and synovial tissues was significantly reduced in a hyaluronate group relative to a control group, and they suggested that the inhibition of nitric oxide production was a mechanism underlying the therapeutic effect of HA. The macroscopic and microscopic findings obtained in our study highlight the chondroprotective activity of intra-articularly administered hyaluronate.

\section{Study Limitations}

This study had some limitations. First, the number of rabbits in each group was small. Second, a more objective and measurable outcome and evaluation system, such as immunohistochemical analysis of the cartilage could have been adopted. However, our findings in this study may bring new insights in the treatment of $\mathrm{OA}$ using combined treatment of SCD and bone marrow injection. Importantly, future studies are needed.

\section{CONCLUSION}

In conclusion, this study showed that SCD with intraarticular bone marrow injection slowed the progression of $\mathrm{OA}$ and better protected the cartilage surface during the early stages of OA than HA. Nevertheless, a prospective randomized control study with immunohistochemical parameters and radiological should be designed to improve the clinical relevance. 
Ethics Committee Approval: The Laboratory Animal Ethics Committee of Abant Izzet Baysal University, Bolu/Turkey (decision no: 2017/20) approved this study.

Conflict of Interest: No conflict of interest was declared by the authors.

Financial Disclosure: The authors declared that this study received no financial support.

Etik Kurul Onayı: Abant İzzet Baysal Üniversitesi Laboratuvar Hayvanları Etik Kurulu, Bolu/Türkiye (karar no: 2017/20) çalışmayı onayladı.

\section{Çıkar Çatışması: Yazarlar tarafından çıkar çatışması} bildirilmemiştir.

Finansal Destek: Yazarlar tarafından finansal destek almadıkları bildirilmiştir.

\section{REFERENCES}

1. Cross M, Smith E, Hoy D, Nolte $S$, Ackerman I, Fransen M, Bridgett L, Williams S, Guillemin F, Hill CL, Laslett LL, Jones G, Cicuttini F, Osborne R, Vos T, Buchbinder R, Woolf A, March L. The global burden of hip and knee osteoarthritis: estimates from the global burden of disease 2010 study. Ann Rheum Dis. 2014;73:1323-30.

2. Oliveira MZ, Albano MB, Stirma GA, Namba MM, Vidigal L, Cunha LAMD. Intra-articular viscosupplementation of hyaluronic acids in an experimental osteoarthritis model. Rev Bras Ortop. 2018;53:293-9.

3. Patel A, Pavlou G, Mújica-Mota RE, Toms AD. The epidemiology of revision total knee and hip arthroplasty in England and Wales: A comparative analysis with projections for the United States. A study using the National Joint Registry dataset. Bone Joint J. 2015;97-B:107681.

4. Kurtz S, Ong KL, Lau E, Mowat F, Halpern M. Projections of primary and revision hip and knee arthroplasty in the United States from 2005 to 2030. J Bone Joint Surg Am. 2007;89:780-5.

5. Mont MA, Issa K. Updated projections of total joint arthroplasty demands in America. Commentary on an article by Steven M. Kurtz, PhD, et al.: "Impact of the Economic Downturn on Total Joint Replacement Demand in the United States. Updated Projections to 2021" J Bone Joint Surg Am. 2014;96:e68.

6. Ertürk C, Altay MA, Altay N, Kalender AM, Öztürk IA. Will a single periarticular lidocaine-corticosteroid injection improve the clinical efficacy of intraarticular hyaluronic acid treatment of symptomatic knee osteoarthritis? Knee Surg Sports Traumatol Arthrosc. 2016;24:3653-60.

7. Feeley BT, Gallo RA, Sherman S, Williams RJ. Management of osteoarthritis of the knee in the active patient. J Am Acad Orthop Surg. 2010;18:406-16.

8. Watterson JR, Esdaile JM. Viscosupplementation: therapeutic mechanisms and clinical potential in osteoarthritis of the knee. J Am Acad Orthop Surg. 2000;8:277-84.

9. Kilic B, Demiroglu M, Ozkan FU, Soylemez MS, Turkmen I, Saglam Y, Ozkan K. Osteoarthritis: can it be reversed? A new biological treatment technique for treating patients with moderate to advanced gonarthrosis. Acta Med Mediterr. 2017;33:335-40.
10. Pan J, Zhou X, Li W, Novotny JE, Doty SB, Wang L. In situ measurement of transport between subchondral bone and articular cartilage. J Orthop Res. 2009;27:1347-52.

11. Hauser RA, Orlofsky A. Regenerative injection therapy with whole bone marrow aspirate for degenerative joint disease: a case series. Clin Med Insights Arthritis Musculoskelet Disord. 2013;6:65-72.

12. Bendele AM. Animal models of osteoarthritis. J Musculoskelet Neuronal Interact. 2001;1:363-76.

13. Ojanen SP, Finnilä MAJ, Mäkelä JTA, Saarela K, Happonen E, Herzog W, Saarakkala S, Korhonen RK. Anterior cruciate ligament transection of rabbits alters composition, structure and biomechanics of articular cartilage and chondrocyte deformation 2 weeks post-surgery in a sitespecific manner. J Biomech. 2020;98:109450.

14. Meachim G. Light microscopy of Indian ink preparations of fibrillated cartilage. Ann Rheum Dis. 1972;31:457-64.

15. Pritzker KP, Gay S, Jimenez SA, Ostergaard K, Pelletier JP, Revell PA, Salter D, van den Berg WB. Osteoarthritis cartilage histopathology: grading and staging. Osteoarthr Cartil. 2006;14:13-29.

16. Schiavinato A, Finesso M, Cortivo R, Abatangelo G. Comparison of the effects of intra-articular injections of hyaluronan and its chemically cross-linked derivative (Hylan G-F20) in normal rabbit knee joints. Clin Exp Rheumatol. 2002;20:445-54.

17. Yoshimi T, Kikuchi T, Obara T, Yamaguchi T, Sakakibara Y, Itoh H, Iwata $H$, Miura T. Effects of high-molecular-weight sodium hyaluronate on experimental osteoarthrosis induced by the resection of rabbit anterior cruciate ligament. Clin Orthop Relat Res. 1994;298:296-304.

18. Wang $C T$, Lin $Y T$, Chiang BL, Lin YH, Hou SM. High molecular weight hyaluronic acid down-regulates the gene expression of osteoarthritisassociated cytokines and enzymes in fibroblast-like synoviocytes from patients with early osteoarthritis. Osteoarthr Cartil. 2006;14:1237-47.

19. Aaron RK, Racine J, Dyke JP. Contribution of circulatory disturbances in subchondral bone to the pathophysiology of osteoarthritis. Curr Rheumatol Rep. 2017;19:49.

20. AlFaqeh H, Nor Hamdan BMY, Chen HC, Aminuddin BS, Ruszymah BHI. The potential of intra-articular injection of chondrogenic-induced bone marrow stem cells to retard the progression of osteoarthritis in a sheep model. Exp Gerontol. 2012;47:458-64.

21. Alfaqeh H, Norhamdan MY, Chua KH, Chen HC, Aminuddin BS, Ruszymah BHI. Cell Therapy for osteoarthritis in Sheep Model, gross and histological assessment. Med J Malaysia. 2008;63 Supplement A:37-8.

22. Gnecchi M, Zhang Z, Ni A, Dzau VJ. Paracrine mechanisms in adult stem cell signaling and therapy. Circ Res. 2008;103:1204-19.

23. Ratajczak MZ, Kucia M, Jadczyk T, Greco NJ, Wojakowski W, Tendera M, Ratajczak J. Pivotal role of paracrine effects in stem cell therapies in regenerative medicine: can we translate stem cell-secreted paracrine factors and micro vesicles into better therapeutic strategies? Leukemia. 2012;26:1166-73.

24. Kobayashi K, Amiel M, Harwood FL, Healey RM, Sonoda M, Moriya $H$, Amiel D. The long-term effects of hyaluronan during development of osteoarthritis following partial meniscectomy in a rabbit model. Osteoarthr Cartil. 2000;8:359-65.

25. Takahashi K, Hashimoto S, Kubo T, Hirasawa Y, Lotz M, Amiel D. Hyaluronan suppressed nitric oxide production in the meniscus and synovium of rabbit osteoarthritis model. J Orthop Res. 2001;19:500-3. 